\title{
Sedimentary deposits left by the 2004 Indian Ocean tsunami on the inner continental shelf offshore of Khao Lak, Andaman Sea (Thailand)
}

\author{
D. Sakuna ${ }^{1,2}$, W. Szczuciński ${ }^{3}$, P. Feldens ${ }^{1}$, K. Schwarzer ${ }^{1}$, and S. Khokiattiwong ${ }^{2}$ \\ ${ }^{1}$ Institute of Geosciences Sedimentology, Coastal and Continental Shelf Research, University of Kiel, \\ Otto-Hahn-Platz 1, D-24118 Kiel, Germany \\ ${ }^{2}$ Oceanography and Environment Unit, Phuket Marine Biological Center, P.O. Box 60, Phuket 83000, Thailand \\ ${ }^{3}$ Institute of Geology, Adam Mickiewicz University, Maków Polnych 16, 61-606 Poznań, Poland
}

(Received November 24, 2010; Revised May 3, 2011; Accepted June 15, 2011; Online published October 24, 2012)

\begin{abstract}
Tsunami waves leave sedimentary signatures both onshore and offshore, although the latter are hardly known. The objective of the present study is to provide new evidence for the 2004 Indian Ocean tsunami deposits left on the inner continental shelf of the Andaman Sea (Thailand) and to identify diagnostic sedimentological and geochemical properties of these deposits. Based on extensive seafloor mapping, three sediment cores were selected for study and were analysed for their sedimentary structures, grain size composition, chemical elemental composition, physical properties and ${ }^{210} \mathrm{~Pb}$ activity. Sediment cores retrieved from shallow water $(9-15 \mathrm{~m})$ within $7.5 \mathrm{~km}$ off the shore revealed distinct event layers, which were interpreted as being tsunami deposits. These $20-25 \mathrm{~cm}$ thick deposits were already covered with post-tsunami marine sediments. They were composed of several units, marine sand layers alternating with poorly sorted mud with terrigenous and anthropogenic components, representing different hydrodynamic conditions (probably during run-up and backwash phase). These sedimentological observations were supported by geochemical and physical data and were confirmed using ${ }^{210} \mathrm{~Pb}$ dating. A sediment core taken from a depth of $57 \mathrm{~m}$ at a distance of $25 \mathrm{~km}$ offshore did not reveal clear event deposits. Comparisons with available data from offshore tsunami deposits showed that there is no single set of signatures that could be applied to identify this kind of deposits.
\end{abstract}

Key words: 2004 Indian Ocean tsunami, offshore tsunami deposits, sedimentology, Khao Lak, Thailand.

\section{Introduction}

Tsunamis are relatively frequent phenomena that occur worldwide (Scheffers and Kelletat, 2003). Recent examples of tsunamis include the 2004 Indian Ocean tsunami, tsunamis in Java in 2006 and Samoa in 2009, the Chilean tsunami in 2010 and the 2011 Tohoku tsunami in Japan. These events can have potentially large impacts on both the coastal zone and the continental shelf. As tsunami waves propagate into shallower water, they can erode, transport and deposit large amounts of sediments both onshore and offshore (e.g., Paris et al., 2010; Goto et al., 2011). Due to the number of processes involved (Shanmugam, 2011), tsunami deposits are very complex in terms of a number of characteristics, including grain size, sedimentary structures and sediment components (e.g., Luque et al., 2001; van den Bergh et al., 2003; Fujiwara and Kamataki, 2007; Kortekaas and Dawson, 2007; Noda et al., 2007; Paris et al., 2010; Chagué-Goff et al., 2011). Geological and environmental impacts of onshore tsunami deposits have been intensively studied in recent years (see Bourgeois, 2009 for a review), whereas the offshore behaviour and effects of tsunami waves during run-up and backwash are still poorly understood.

Copyright (c) The Society of Geomagnetism and Earth, Planetary and Space Sciences (SGEPSS); The Seismological Society of Japan; The Volcanological Society of Japan; The Geodetic Society of Japan; The Japanese Society for Planetary Sciences; TERRAPUB.

doi:10.5047/eps.2011.08.010
A basic problem in studying tsunamis is that our knowledge of the sedimentological features of offshore tsunami deposits is limited to a small number of case studies (e.g., van den Bergh et al., 2003; Noda et al., 2007; Paris et al., 2010). Tsunami impacts (erosion) on the seafloor have primarily been examined indirectly through studies of onshore deposits containing marine microfossils such as foraminifera (e.g., Hawkes et al., 2007; Uchida et al., 2010) or diatoms (e.g., Dawson, 2007; Sawai et al., 2009). The studies of shallow marine tsunami deposits that have been conducted to date have indicated that there is a large variability in the characteristics of these deposits. For instance, a distinct sandy layer was deposited by a tsunami generated during the Krakatau eruption in an embayment next to Java Island (van der Bergh et al., 2003). Around Banda Aceh, which was the most severely devastated region during the 26 December 2004 tsunami, this event left large fields of boulders on land and offshore (Paris et al., 2010). Displaced boulders were also previously reported by Goto et al. (2007) and Feldens et al. (2009) from the Andaman Sea coast and shelf, respectively. Sugawara et al. (2009) reported nearshore impacts of the 2004 tsunami in the Andaman Sea in water depths of 6 to $30 \mathrm{~m}$ based on the distribution of foraminifera in surface sediments. In several other studies (e.g., Abrantes et al., 2008; Goodman-Tchernov et al., 2009; Smedile et al., 2011), offshore tsunami deposits were interpreted from event layers composed of sediments that were coarser than the ambient marine sediments, 
contained indicators of a terrigenous provenance and specific microfossil assemblages. However, there have been no unique criteria for identifying offshore tsunami deposits. Recently, Goto et al. (2011) used repeated bathymetrical surveys and modelling and found that the amount of sediments mobilised by tsunamis is much more substantial offshore than on land.

Shallow water tsunami deposits from uplifted marine sedimentary strata were investigated by Fujiwara and Kamataki (2007) in Japan, and by Cantalamessa and Celma (2005) and Le Roux and Vargas (2005) in Chile. However, these older deposits can be reinterpreted, as in the case of backwash deposits in a shallow marine Miocene setting on the Mejillones Peninsula in northern Chile (Cantalamessa and Celma, 2005), which were recently found to be debris flow deposits with no evidence permitting an interpretation as tsunami deposits of any kind (Bahlburg et al., 2010).

The above examples indicate the limitations of our understanding of the processes of erosion and deposition in shallow marine settings during tsunami events and the difficulties of identifying offshore tsunami deposits. Significant progress in the search for diagnostic criteria may be accomplished only through an increased number of welldocumented case studies of modern tsunami deposits. The objective of this study is to provide evidence that the impact of the 2004 Indian Ocean tsunami can be identified in shallow water deposits offshore Khao Lak by using sedimentological methods and geochemical proxies.

\section{Study Area}

The study area is located on the continental shelf of the Andaman Sea offshore Khao Lak (Phang Nga province, Thailand) and extends to a distance of about $25 \mathrm{~km}$ offshore (Fig. 1). The coast is composed of embayed areas with sandy beaches separated by rocky headlands. The shelf is relatively flat and sloping offshore, reaching water depths of $50 \mathrm{~m}$ at a distance of $25 \mathrm{~km}$ from the coastline. The sea bottom is mainly composed of sand, sandy mud, muddy sand and bedrock outcrops (Usiriprisan et al., 1987; Di Geronimo et al., 2009; Feldens et al., 2009, 2012). In some regions, the seabed was subjected to offshore tin mining (Usiriprisan et al., 1987). The climate of this region is dominated by monsoons, with the southwest monsoon remaining active from May to September and generating heavy rainfall during this period. The northeast monsoon lasts from December to February and results in a calm, dry season (Khokiattiwong et al., 1991). The study area is located next to the area in Thailand which was most damaged during the 2004 Indian Ocean tsunami (Bell et al., 2005; Szczuciński et al., 2006). Moreover, strong storms are rare in this area, increasing the preservation potential of tsunami deposits on the seafloor (Jankaew et al., 2008; Kumar et al., 2008). Previous post-tsunami seafloor mapping surveys (Di Geronimo et al., 2009; Feldens et al., 2009) reported discontinuous muddy sediment patches and a channel-like system next to an ancient reef platform located in shallow water (5 to $15 \mathrm{~m})$. Consolidated mud deposits containing grass, wood and shell fragments, likely transported by the backwash flow in the 2004 tsunami, were observed in grab samples and short cores (Feldens et al., 2009). Based on these data and further hydroacoustic surveys (Feldens et al., 2012), new target areas for sediment coring were selected (Figs. 1 and 2) to examine modern offshore tsunami deposits.

\section{Methods}

High resolution hydroacoustic mapping (Feldens et al., 2009, 2012) was performed during three research cruises (Nov.-Dec. 2007, Nov.-Dec. 2008 and Feb.-Mar. 2010). Data from these surveys form the basis for the selection of sediment coring sites. Sixty sediment cores were collected using a $2 \mathrm{~m}$ long Ruhmor type gravity corer in water depths of 5 to $70 \mathrm{~m}$. Three cores were selected for the present study (Figs. 1 and 2, Table 1), two of which were obtained in water depths of 9.6 and $14.4 \mathrm{~m}$, located 3.1 and $7.2 \mathrm{~km}$ offshore, respectively, while the third core was collected further offshore at a water depth of $57 \mathrm{~m}, 25.5 \mathrm{~km}$ offshore. Moreover, three samples from sites located within various onshore environments that had been subjected to tsunami erosion (pre-tsunami soils, mangrove soils, coastal plain sands) were obtained to provide data on terrigenous geochemical end-members (Fig. 1).

The cores were first analysed using non-destructive techniques; a Multi-sensor core logger (MSCL) and an X-ray fluorescence (XRF) core scanner. The following basic physical and acoustical sediment properties were measured: bulk density, gamma-ray attenuation, magnetic susceptibility and $p$-wave velocity. These physical properties are commonly used to find distinct layers such as debris flows and turbidites within sediment cores (Weber et al., 1997; Best and Gunn, 1999; Hofmann et al., 2005). An XRF core scanner was used to semi-quantitatively assess sediment composition; this method can serve as a tool for differentiating terrigenous materials from marine sediments (Lamy et al., 2001; Bahr et al., 2005; Ohta and Arai, 2007). The measurements were taken every centimetre directly at the surface of a split core. The instrument was set to a count time of $30 \mathrm{~s}$ with a voltage of $10 \mathrm{kV}$. At this setting, the measurement range covered thirteen elements (Al, Si, P, S, Cl, $\mathrm{K}, \mathrm{Ca}, \mathrm{Ti}, \mathrm{V}, \mathrm{Cr}, \mathrm{Mn}, \mathrm{Fe}$ and $\mathrm{Rh}$ ). Data were provided as relative element intensities in counts per second (cps). These intensities depend mainly on element concentration, matrix effects and physical properties, as well as sample geometry (Jansen et al., 1998; Weltji and Tjallingii, 2008).

The relative concentrations of eight elements, Al, Si, $\mathrm{S}, \mathrm{K}, \mathrm{Ca}, \mathrm{Ti}, \mathrm{Mn}$ and Fe from onshore samples (10120789, 101207-91 and 101207-93) and samples from core 050310-C6, were analysed using principal component analysis (PCA) to evaluate the sediment provenance (Marques et al., 2008; Heise et al., 2010). Four elements were not used, due to either very low concentrations in some samples (at detection limits: $\mathrm{P}, \mathrm{V}, \mathrm{Cr}, \mathrm{Rh}$ ) or possible changes due to sample preparation $(\mathrm{Cl})$. PCA is a data reduction technique used to convert a large number of geochemical variables into a small set of new variables called principal components or factors (PC) and to group samples based on their geochemistry (Ohta and Arai, 2007; Reid and Spencer, 2009).

Digital X-radiography images were obtained from $1 \mathrm{~cm}$ thick slabs taken from the surface of split sediment cores. 


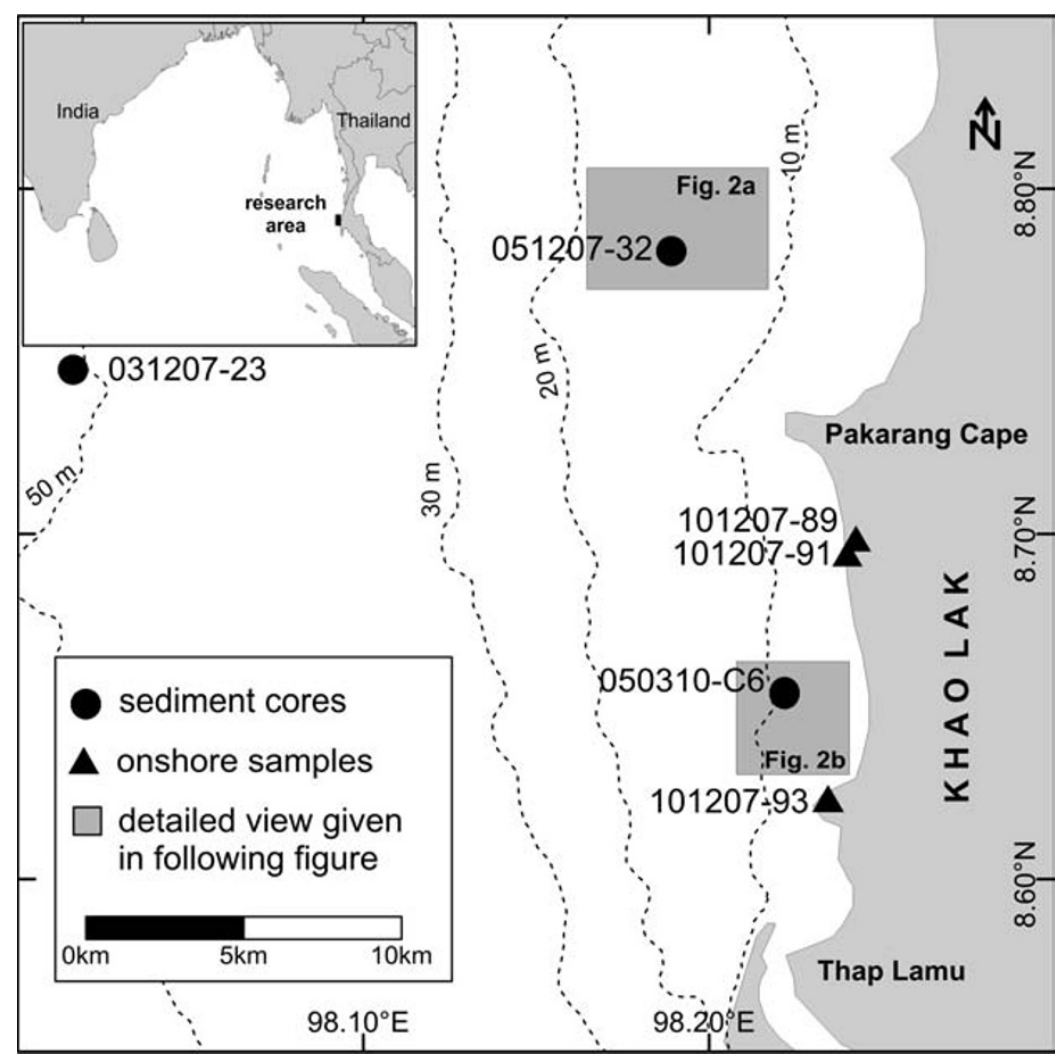

Fig. 1. Overview of the investigation area. Bathymetric data are based on nautical chart. The inset shows location of the study area within the Indian Ocean basin.
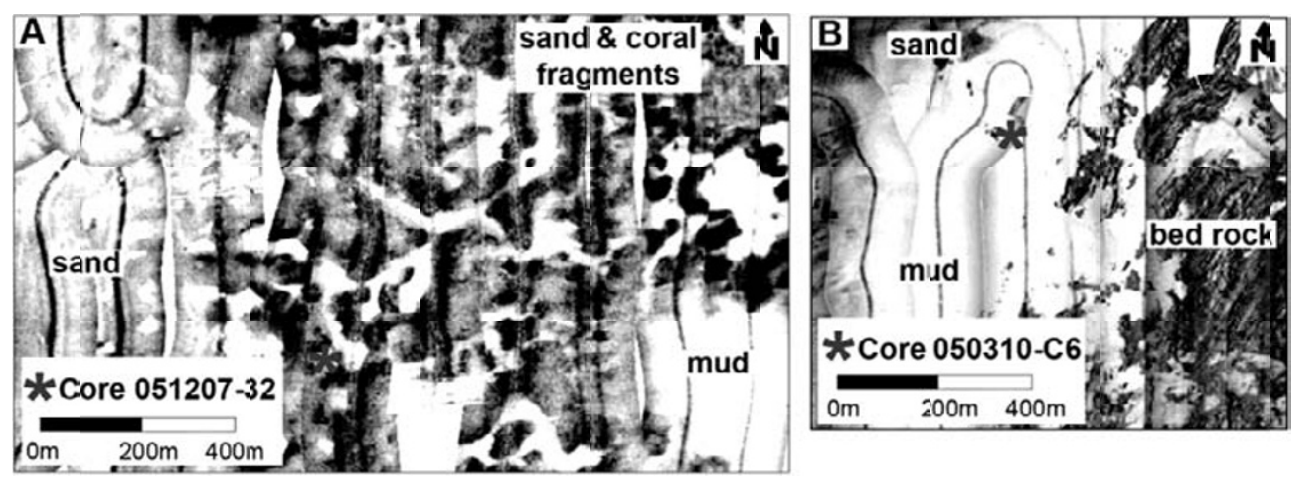

Fig. 2. Side scan sonar mosaics (refer to Fig. 1 for positions). The images show the location of sediment cores. (A) Sediment core 051207-32 was retrieved from a small mud-filled channel (displayed in light grey). The channels are separated by coarse sand, frequently containing coral fragments (displayed in dark grey). Further offshore, medium to coarse sands are deposited (displayed in intermediate grey). (B) Sediment core 050310-C6 was retrieved from a large patch covered by silty sediments (displayed in light gray) seaward of granitic bedrock outcrops. Coarse sands are deposited further offshore (displayed in dark grey).

Table 1. List of the analyzed sediment cores.

\begin{tabular}{ccccccc}
\hline Core no. & $\begin{array}{c}\text { Sampling } \\
\text { year }\end{array}$ & $\begin{array}{c}\text { Latitude } \\
(\mathrm{N})\end{array}$ & $\begin{array}{c}\text { Longitude } \\
(\mathrm{E})\end{array}$ & $\begin{array}{c}\text { Water } \\
\text { depth } \\
(\mathrm{m})\end{array}$ & $\begin{array}{c}\text { Core } \\
\text { recovery } \\
(\mathrm{cm})\end{array}$ & $\begin{array}{c}\text { Distance } \\
\text { offshore } \\
(\mathrm{km})\end{array}$ \\
\hline $050310-\mathrm{C6}$ & 2010 & $08^{\circ} 38.761^{\prime}$ & $98^{\circ} 12.967^{\prime}$ & 9.6 & 99 & 3.1 \\
$051207-32$ & 2007 & $08^{\circ} 46.725^{\prime}$ & $98^{\circ} 11.814^{\prime}$ & 14.4 & 30 & 7.2 \\
$031207-23$ & 2007 & $08^{\circ} 44.879^{\prime}$ & $98^{\circ} 01.173^{\prime}$ & 57.0 & 70 & 25.5 \\
\hline
\end{tabular}

This technique is used to detect any internal sedimentary structures or unconformities not visible to the naked eye. The images (Figs. 3-5) show the relative change in sediment bulk density. High bulk density sediment, such as pebbles, shell fragments or sand, reduce X-ray penetration and are displayed in light grey, whereas low bulk density sediment, as observed for fine-grained sediments, is represented by dark grey or black (Bouma, 1964). 


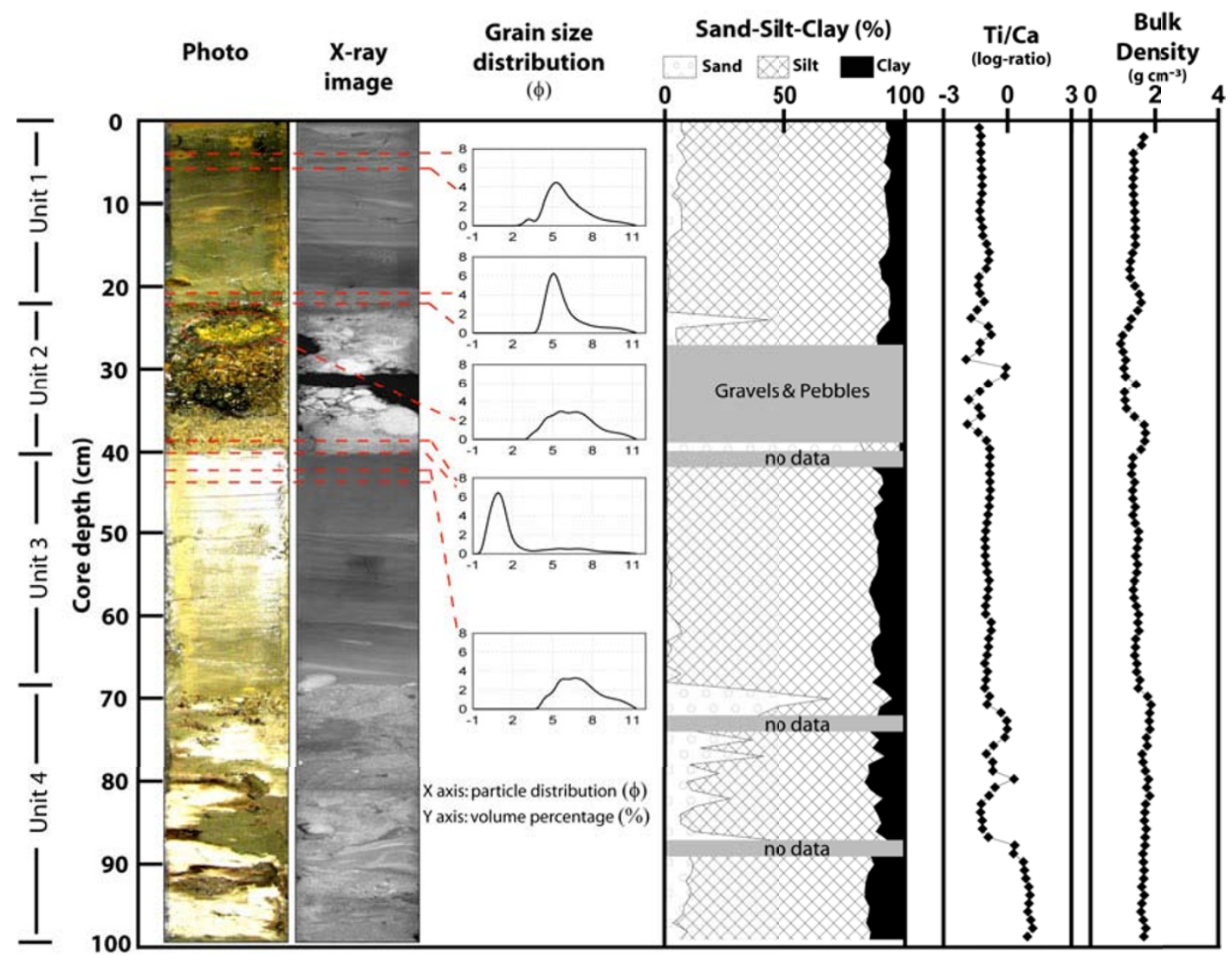

Fig. 3. Properties of sediments in core 050310-C6: division into sedimentary units, photo, X-ray image, typical grain size distributions ( $\phi$ ), amount of sand, silt and clay fraction (\%), Ti/Ca log-ratio and bulk density.

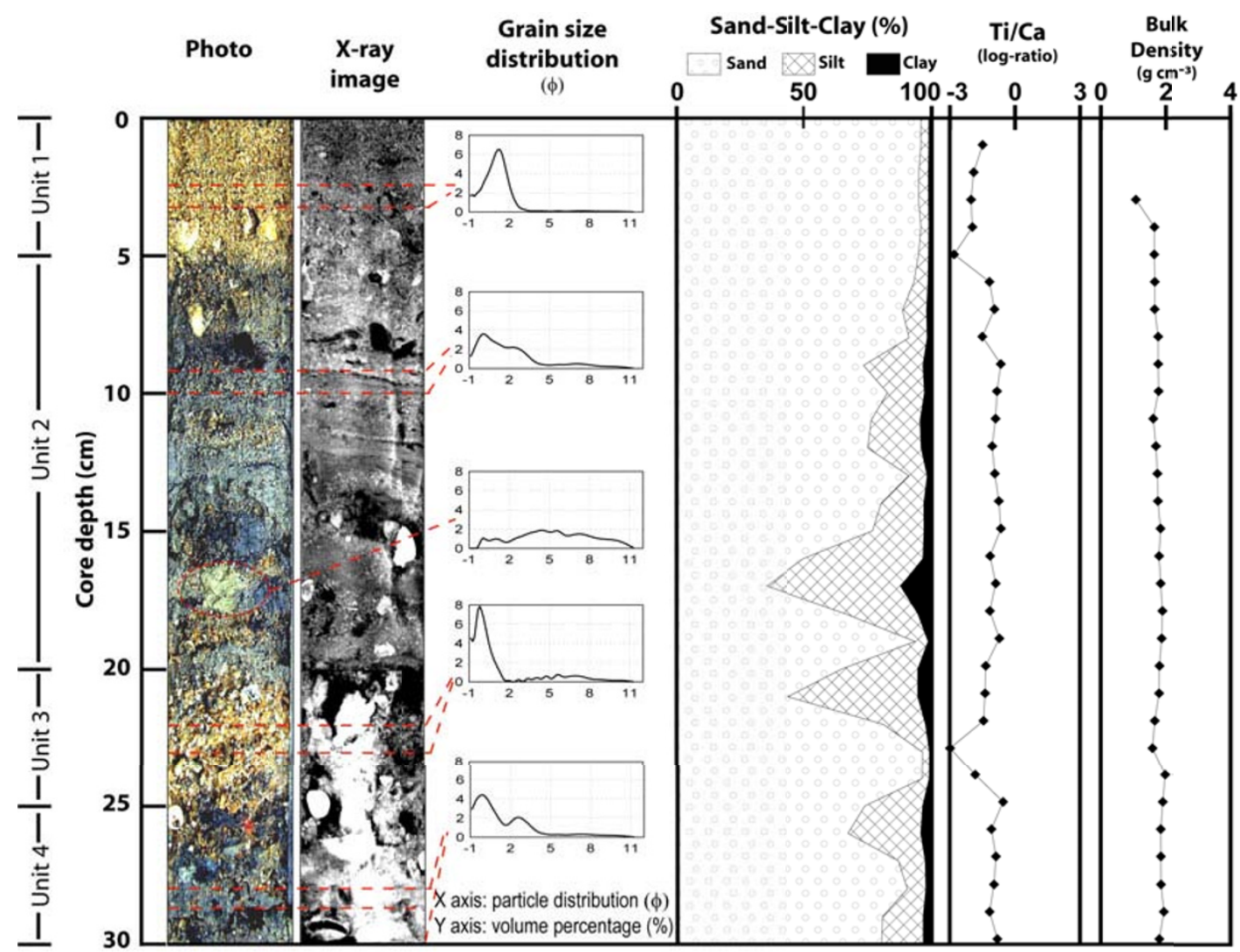

Fig. 4. Properties of sediments in core 051207-32: division into sedimentary units, photo, X-ray image, typical grain size distributions $(\phi)$, amount of sand, silt and clay fraction (\%), Ti/Ca log-ratio and bulk density. 


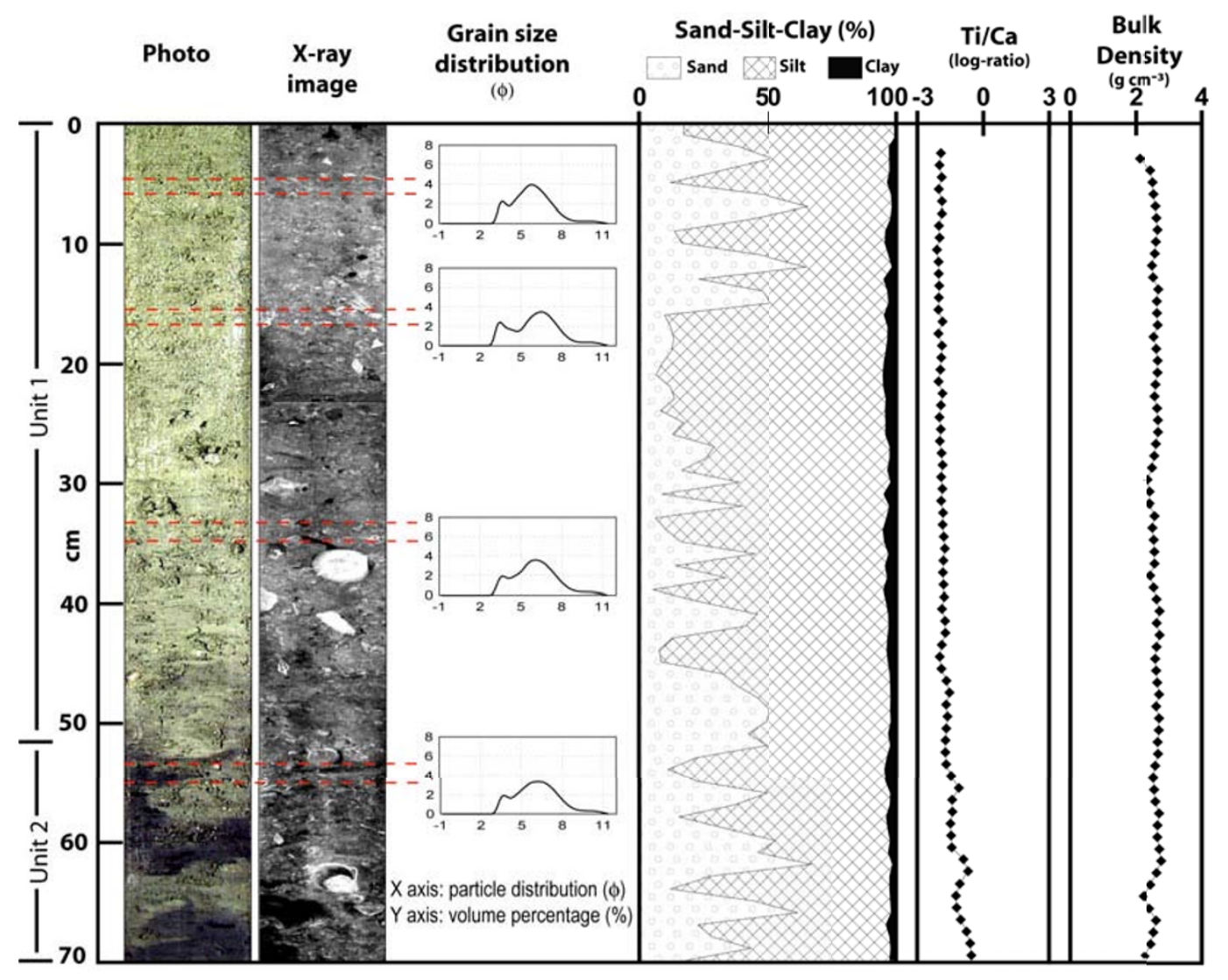

Fig. 5. Properties of sediments in core 031207-23: division into sedimentary units, photo, X-ray image, typical grain size distributions $(\phi)$, amount of sand, silt and clay fraction (\%), Ti/Ca log-ratio and bulk density.

To determine the grain size distribution, core materials were sampled in $1 \mathrm{~cm}$ intervals. The materials were digested with $\mathrm{HCl}$ and $\mathrm{H}_{2} \mathrm{O}_{2}$ to remove carbonates and organic matter prior to analysis with a Coulter LS-13320 laser-based particle sizer device with a measuring range of 0.04 to $2000 \mu \mathrm{m}$. From core 050310-C6, samples composed mainly of grains in excess of sand size (27-38, 40$41,72-73$ and $87-88 \mathrm{~cm}$ ) were not analysed. Statistical parameters of the grain size distribution (Figs. 3-5) were calculated using the logarithmic method of moments in GRADISTAT software (Blott and Pye, 2001).

${ }^{210} \mathrm{~Pb}$ dating has been widely used for the assessment of sediment accumulation rates over the last 100 years. Total ${ }^{210} \mathrm{~Pb}$ activity in the recent sediments comes primarily from two sources: supported (autochthonous) ${ }^{210} \mathrm{~Pb}$ is produced by the radioactive decay of uranium radioactive chain isotopes in sediments and excess (allochthonous) ${ }^{210} \mathrm{~Pb}$ is produced by the decay of ${ }^{222} \mathrm{Rn}$, mostly in the atmosphere, and is then deposited with the sediments. The excess ${ }^{210} \mathrm{~Pb}$ activity profile in the sediments is commonly characterised by the maximum activity at the surface and by the exponential decay, and is used for the assessment of sediment accumulation rates under several assumptions, depending on the applied model (Robbins and Edgington, 1975; Nittrouer $e t$ al., 1979; Carpenter et al., 1982). However, the shape of the ${ }^{210} \mathrm{~Pb}$ profile may also reveal information on changes in sediment accumulation rates, the presence of major erosional events and the presence of event layers (e.g., Nittrouer $e t$ al., 1979; Jaeger et al., 1998; Sommerfield and Nittrouer,
1999; Crockett et al., 2008; Szczuciński et al., 2009). An event layer can usually be observed in the portion of the ${ }^{210} \mathrm{~Pb}$ activity profile that shows no change downcore (usually due to rapid deposition during the event). However, more frequently, ${ }^{210} \mathrm{~Pb}$ depletion is observed due to dilution processes in larger sediment masses and/or the admixture of sediments containing low ${ }^{210} \mathrm{~Pb}$ activity due to a coarser grain size fraction.

${ }^{210} \mathrm{~Pb}$ activity was measured for samples from core 050310-C6 using gamma spectrometry at the LeibnizLaboratory for Radiometric Dating and Isotope Research (Kiel, Germany). The ${ }^{210} \mathrm{~Pb}$ supported activities in the present study were assessed from minimum activities (40 $\mathrm{Bq} \mathrm{kg}^{-1}$ ) found in the sediment core, which are similar to the supported activities reported for similar sediments in the region (Szczuciński, 2010). However, supported activities are typically ascertained by averaging the nearly uniform, low-level ${ }^{210} \mathrm{~Pb}$ activities below the region of radioactive decay or through independent measurements of ${ }^{226} \mathrm{Ra}$ (often through ${ }^{214} \mathrm{~Pb}$ and ${ }^{214} \mathrm{Bi}$; e.g., Zaborska et al., 2007; Szczuciński et al., 2009). Because the uniform activities in the lowermost part of the core were not reached and the ${ }^{226} \mathrm{Ra}$ was not measured, a precise estimation of ${ }^{210} \mathrm{~Pb}$ supported activities could not be obtained. Supported ${ }^{210} \mathrm{~Pb}$ activity values in the order of 10 to $26 \mathrm{~Bq} \mathrm{~kg}^{-1}$ were also reported by Kennedy et al. (2008) from the nearshore sediments on the Andaman Sea coast and are considered in the discussion of the calculated accumulation rates. The linear sediment accumulation rate (SAR) was determined from 
the decline in the excess ${ }^{210} \mathrm{~Pb}$ activities using the following equation (Robbins and Edgington, 1975; McKee et al., 1983):

$$
\mathrm{SAR}=\lambda \times z \times\left[\ln \left(A_{0} / A_{z}\right)\right]^{-1}
$$

where $\lambda$ is the decay constant $\left(=0.0311\right.$ year $\left.^{-1}\right)$;

$z$ is the depth in the core $(\mathrm{cm})$

$A_{0}$ is the specific activity of excess ${ }^{210} \mathrm{~Pb}$ at a particular reference horizon $\left(\mathrm{Bq} \mathrm{kg}^{-1}\right)$

$A_{z}$ is the specific activity of excess ${ }^{210} \mathrm{~Pb}$ at depth $z$ below the reference horizon $\left(\mathrm{Bq} \mathrm{kg}^{-1}\right)$.

Along with ${ }^{210} \mathrm{~Pb},{ }^{137} \mathrm{Cs}$ activity was measured using gamma spectrometry.

\section{Results}

In water depths of 5 to $20 \mathrm{~m}$, several regions covered with mud or revealing a channel-like morphology (Di Geronimo et al., 2009; Feldens et al., 2009, 2010, 2012), were found to host tsunami deposits. Representative sediment cores from these regions were selected for the present study (core 050310-C6 from a mud patch and core 051207-32 from the channel).

\subsection{Sedimentary structure and grain size}

Core 050310-C6, with a length of $99 \mathrm{~cm}$, was retrieved from a water depth of $9.6 \mathrm{~m}$ (see Figs. 1 and 2 and Table 1). The core was subdivided into four major sedimentary units (Fig. 3).

- Unit $1(0-22 \mathrm{~cm})$, was composed of brown, poorly sorted laminated silt that contained up to $10.8 \%$ clay and up to $8.4 \%$ sand. Only a few bioturbation traces were preserved. This unit was divided into three subunits. The upper part (subunit 1a, $0-15 \mathrm{~cm}$ ) was very finely laminated. It contained both horizontal and cross laminations, as well as erosional surfaces. Greyscale changes of the $\mathrm{x}$-ray image suggested slight upward fining within the laminae. The second subunit $(1 \mathrm{~b}, 15-20 \mathrm{~cm})$ was composed mostly of silt. In comparison to the units located above and below this subunit, it was slightly depleted in sand and enriched in clay. It contained very gently marked horizontal laminations. The upper contact was transitional while the lower contact was sharp. The lower subunit (1c, 20$22 \mathrm{~cm}$ ) was composed of slightly coarser silt than the subunit above. The sediment was fining upward and conformably overlaid the sediments of unit 2 .

- Unit $2(22-40 \mathrm{~cm})$ was composed of sand, gravel, clay clasts, pieces of laterites, rocks and shells. The arrangement of these particles was subhorizontal, with the largest clasts being up to $3 \mathrm{~cm}$ in diameter. Based on a detailed analysis, this unit was divided into two subunits. The upper subunit $2 \mathrm{a}(22-38 \mathrm{~cm})$ was composed of sediments ranging from normal grading gravels to fine sand. The lower contact with subunit $2 b$ was erosional. Subunit $2 \mathrm{~b}(38-40 \mathrm{~cm})$ was composed of laminated medium to coarse sand.

- Unit 3 (40-69 cm) was represented by laminated silt and clayey silt that was slightly finer than the sediment forming unit 1. Its upper contact was erosional and the basal contact was sharp. Within this unit, at least three fining-upward sequences were differentiated (3a:
40-50 cm, 3b: 50-61 cm, and 3c: 61-69 cm). These sequences began with thin sandy silt laminae and became finer with decreasing depth, eventually becoming clayey silt. Moreover, in subunit $3 \mathrm{~b}$, an erosional surface was preserved in the middle of the subunit. The lamination in the unit was slightly inclined, and few small vertical burrows were preserved. A $2 \mathrm{~cm}$ diameter gravel was found at the bottom of this unit.

- Unit 4 (69-99 cm) was composed of laminated muddy sand, which was partly intercalated with consolidated mud that was almost white. The layering and laminations were partly disturbed. In the upper $10 \mathrm{~cm}$ of this unit, white consolidated mud did not extend continuously in the horizontal plane, while the lowermost $5 \mathrm{~cm}$ of the sediment in the core was composed entirely of this type of sediment. Some small gravel components were found at a depth of 92-94 cm.

Core 051207-32 was retrieved from a water depth of $14.4 \mathrm{~m}$ and was $30 \mathrm{~cm}$ in length (Figs. 1 and 2, Table 1). This core also revealed several different sediment types, and was therefore divided into four units (Fig. 4):

- Unit $1(0-5 \mathrm{~cm})$ was composed of a yellowish medium to coarse sand with shell fragments. This unit had a massive structure and conformably overlaid the upper surface of unit 2 .

- Unit $2(5-20 \mathrm{~cm})$ had a relatively complex composition. It was composed of consolidated sandy mud, muddy sand and sand. It was variable in colour, ranging from yellow or light green to olive or black. It was partly laminated, but also contained muddy clasts, pieces of wood, laterites and red brick fragments (artefacts). Sand appeared in the form of intercalations. Moreover, gravel and small pebbles were scattered throughout the entire unit. The grain size in this unit did not show normal grading, except for the upper part. The lower contact was sharp and uneven.

- Unit $3(20-25 \mathrm{~cm})$ was a massive layer of coarse sand and gravels.

- Unit $4(25-30 \mathrm{~cm})$ was composed of muddy sand. The upper part contained admixtures of coarse sand from unit 3.

Core 031207-23 was retrieved from a water depth of $55.4 \mathrm{~m}$ and was $70 \mathrm{~cm}$ long (Figs. 1 and 5, Table 1). It was composed of poorly sorted sandy silt and silty sand, with only $5.2 \%$ of clay. Shells were abundant in this core, and it was possible to distinguish two units.

- Unit 1 (comprising the upper approx. $51 \mathrm{~cm}$ ) was composed mostly of silty sand with intercalations of sandy silt. Laminations were poorly preserved and shells were less abundant than in the lower unit. No distinct boundary was observed between the units, and the lower boundary was selected in conjunction with changes in geochemistry. The upper part of the unit contains sandy intercalations of several $\mathrm{cm}$-thick. The lowest sand content was found at a depth of 20-30 cm.

- Unit 2 (approx. 51-70 cm) was also composed of silty sand intercalated with sandy silt. The intercalations appeared in the form of poorly preserved layers. This 


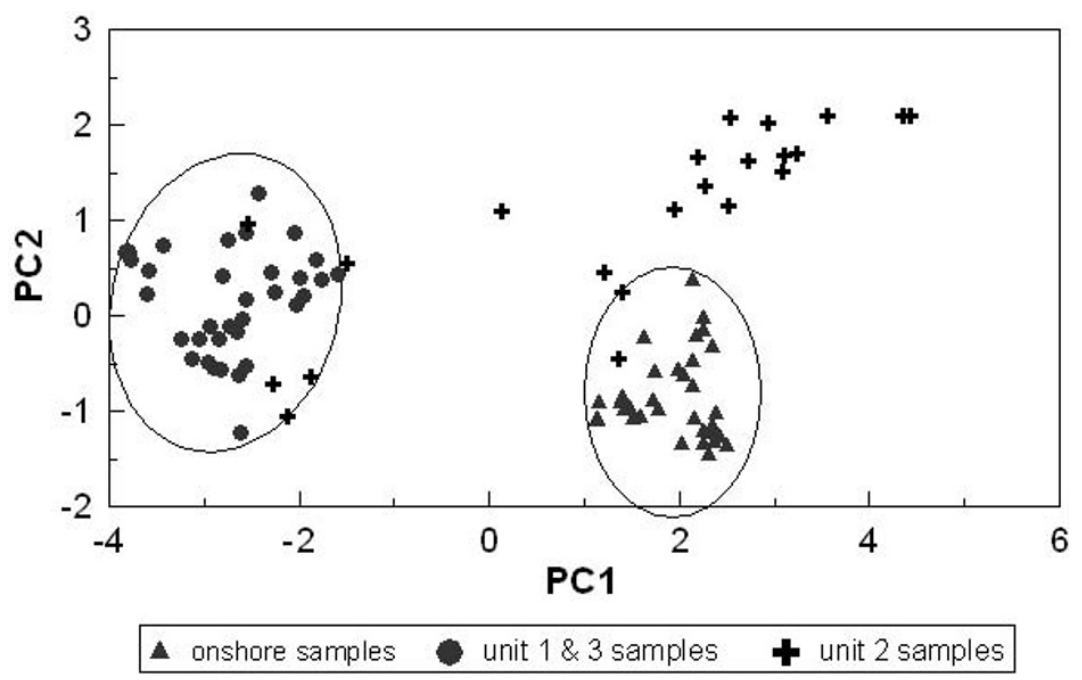

Fig. 6. PCA for chemical elemental composition data (from XRF core scanner) of onshore sediment samples which were retrieved from Khao Lak coastline (101207-89, 101207-91 and 101207-93; see position on Fig. 1) and offshore sediment samples from unit 1, 3 and 2 of core 050310-C6. Unit 1 and 3 are interpreted as post- and pre-tsunami deposits and unit 2 as tsunami deposits.

unit contained more shell fragments than unit 1.

\subsection{Geochemical and physical properties}

Log-ratios of Titanium (Ti) and Calcium (Ca), which represent the relative variations of terrigenous versus marine constituents, are shown in Figs. 3-5. Ti is enriched in tropical soils in the form of laterites and bauxites and is relatively inert against diagenetic processes (Calvert and Pedersen, 2007), whereas $\mathrm{Ca}$ reflects the occurrence of $\mathrm{CaCO}_{3}$, which is mainly produced under marine conditions (Hofmann et al., 2005; Weltji and Tjallingii, 2008). In all of the studied cores, changes in the $\mathrm{Ti} / \mathrm{Ca}$ log-ratio roughly reflected the sedimentary units described above. In core 050310-C6 (Fig. 3), the ratio was stable in units 1 and 3, variable in unit 2 and generally elevated in unit 4 . In core 051207-32 (Fig. 4), this ratio was slightly lower in the sandy, shell-rich units (units 1 and 3). This ratio was mostly uniform in core 031207-23 (Fig. 5), where only a slight downward increase was observed in unit 2.

The PCA revealed that two principal components of onshore samples and sediment samples from core 050310-C6 (PC1 and PC2) explained $80.5 \%$ of the cumulative variance. PC1 (accounting for $69.7 \%$ of the variance) had highly negative factor scores for terrestrial elements, such as $\mathrm{Al}, \mathrm{Si}, \mathrm{S}$, $\mathrm{K}, \mathrm{Ti}, \mathrm{Mn}$ and Fe. PC2 (accounting for $10.8 \%$ of the variance) had highly positive factor scores for $\mathrm{Ca}$ and $\mathrm{Si}$. This finding indicates that $\mathrm{PC} 2$ was characterised by a marine component, and $\mathrm{Si}$ was most likely associated with marine sands. Plotting these two main factors together (Fig. 6) indicates the grouping of sediment samples (circled on the graph). Samples from unit 2 of core 050310-C6 and onshore sediments had positive values for PC1, which indicated a stronger terrestrial influence than units 1 and 3 . For PC2, most of units 1,2 and 3 of core 050310-C6 had positive values, whereas onshore samples had negative values. This finding suggests that unit 2 of core 050310-C6 also had marine components. Therefore, sediments from unit 2 of core 050310-C6 were a mixture of terrestrial and marine components.
The bulk density of the studied cores was generally uniform, with the exception of slight variations in units 2 and 4 of core $050310-\mathrm{C} 6$. The other measured physical properties did not reveal significant changes.

\section{$4.3{ }^{210} \mathrm{~Pb}$ data and interpretation}

The total ${ }^{210} \mathrm{~Pb}$ activity profile of core $050310-\mathrm{C} 6$ (Fig. 7) revealed a general decline of activities with depth, interrupted by one major and several minor anomalies that were interpreted as being event layers or periods of accelerated sediment accumulation. These event layers reflect a nonsteady sedimentation regime.

Using data on sedimentary structures as supporting information, the total ${ }^{210} \mathrm{~Pb}$ profile was divided into three major parts, referred to as sedimentary units 1, 2 and 3 (Fig. 3).

- The upper portion of unit 1 was composed of three sediment segments (approximately $0-15 \mathrm{~cm}, 15-20 \mathrm{~cm}$ and $20-22 \mathrm{~cm}$ ), which were most likely deposited during events or periods of accelerated accumulation, as indicated by step-like activity profiles. The uppermost segment could also be interpreted as a surface mixed layer; however, the well-preserved laminations suggest that sediment mixing due to bioturbation was not significant. Precise calculations of sediment accumulation rates were not possible since the accumulation was not steady and the background activities were only assumed. Depending on the ${ }^{210} \mathrm{~Pb}$ supported activities used and considering the analytical accuracy, the calculated sediment accumulation rates were in the range of 1.3 to $5.7 \mathrm{~cm} \mathrm{y}^{-1}$. In general, the lower the supported activities applied, the higher the accumulation rate that we obtain. Since the assumptions for this method were not fully met (the accumulation was not steady), the results should be regarded as an approximation; we can infer from these results that the accumulation rate occurring is in the order of a few $\mathrm{cm}$ per year. This finding suggests that the unit had to be deposited over a period of several to a dozen years. Considering that the core was sampled in 2010 , it is 


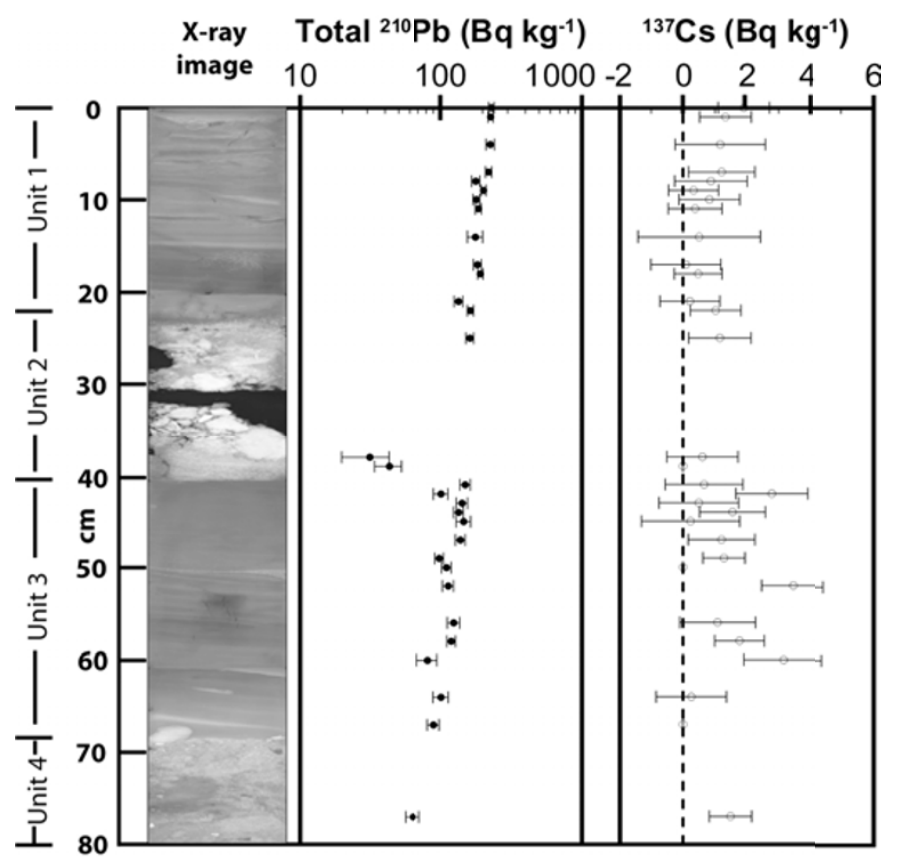

Fig. 7. Total ${ }^{210} \mathrm{~Pb}$ activity $\left(\mathrm{Bq} \mathrm{kg}{ }^{-1}\right)$ profile, ${ }^{137} \mathrm{Cs}$ activity profile and $\mathrm{X}$-ray image of core $050310-\mathrm{C} 6$. The lowest total ${ }^{210} \mathrm{~Pb}$ activity was measured in the sand layer (38-40 cm depth), and is close to assumed supported ${ }^{210} \mathrm{~Pb}$ activity.

possible that the sediments in unit 1 were deposited after 2004.

- Unit 2 (around 22 to $40 \mathrm{~cm}$ ) was partly composed of coarse sediments, which do not contain excess ${ }^{210} \mathrm{~Pb}$, as indicated by a sample taken from a depth of $38 \mathrm{~cm}$ which showed only the activity of supported ${ }^{210} \mathrm{~Pb}$. The activities in the upper part of the unit and below are similar. Therefore, this unit was assumed to be an event layer. Moreover, similar ${ }^{210} \mathrm{~Pb}$ activities in the lowermost part of unit 1 and in the uppermost part of unit 3 also suggested that the event that created unit 2 was effectively depositional and caused little or no erosion of the older sediments.

- Unit 3 (below $40 \mathrm{~cm}$ ) revealed a general decline of ${ }^{210} \mathrm{~Pb}$ activity with depth; however, there were three segments with slightly reversed trends. Those segments were found at approximately the following depths: 40-50, 50-61 and 61-69 cm. These segments roughly corresponded to the fining-upward subunits $3 \mathrm{a}, 3 \mathrm{~b}$ and $3 \mathrm{c}$ and most likely represented sedimentary events or periods of accelerated deposition. Calculations of sediment accumulation rates in this unit, under the conditions specified above, indicated rates of approximately 0.7 to $2.4 \mathrm{~cm} \mathrm{y}^{-1}$.

The ${ }^{137} \mathrm{Cs}$ values indicated very low activities, often close or below minimum detection activity levels (Fig. 7). However, the presence of ${ }^{137} \mathrm{Cs}$ throughout the core supports a ${ }^{210} \mathrm{~Pb}$ based interpretation of a high accumulation rate since ${ }^{137} \mathrm{Cs}$ has been present in the environment since the early $1950 \mathrm{~s}$ (Robbins et al., 1978). The very low activities observed were due in part to high accumulation rates and the dilution effect of the radioisotope in the large mass of sediment, and in part to generally low ${ }^{137} \mathrm{Cs}$ fallout at this latitude (see discussion in Szczuciński et al., 2009).

\section{Discussion}

\subsection{Evidence of the 2004 Indian Ocean tsunami event layer}

Sediment cores were collected within three to six years after the 2004 Indian Ocean tsunami. In the period between the tsunami and the time of collection, neither big storms nor intense anthropogenic offshore activities affected the region. Several tropical cyclones were recorded during the 20th century and passed near the study area; the last major cyclone in this region was Cyclone Gay in 1989 (Kumar et al., 2008; Brand, 2009). However, despite the fact that these events were recorded in middle continental shelf deposits (Szczuciński, 2010), they have not been found to cause significant sedimentological change in the eastern coastal region of the Andaman Sea due to their westward-oriented tracks (Brand, 2009). Consequently, the documented sedimentary event layers found in the inner shelf cores are considered to represent potential effects of the 2004 tsunami. For this event, maximum water velocities over the inner shelf have been modelled and show values in the order of several $\mathrm{m} \mathrm{s}^{-1}$ (Suppasri et al., 2011).

In core $050310-\mathrm{C} 6$, the most likely result of deposition by the 2004 tsunami was sediment unit 2 , which was composed of poorly sorted sand and gravel between fine-grained deposits. This event layer contains compounds of terrestrial and marine origin: clay clasts, pieces of laterites, rocks and shells. The mixed provenance of the sediments was supported by the PCA, evaluating their chemical composition. These sediments were similar to samples taken from potential onshore sources, as well as marine sands (Fig. 6). Unit 2 is also marked by similar ${ }^{210} \mathrm{~Pb}$ activities above and below this unit and by anomalously low ${ }^{210} \mathrm{~Pb}$ activity in some samples taken from this unit, which supports its event origin. The deposits above and below (units 1 and 3) represent rapidly accumulating sediments $\left(>1 \mathrm{~cm} \mathrm{y}^{-1}\right)$ with 
episodes of erosion and sedimentation indicated by sedimentary structures seen in X-radiographs (Fig. 3) and reflecting the dynamic nature of shallow water environments (water depths of approximately $10 \mathrm{~m}$ ). The ${ }^{210} \mathrm{~Pb}$-based assessment of accumulation rates confirmed, within error ranges, that unit 2 was several years old and could have been generated by the 2004 Indian Ocean tsunami.

Core 051207-32 was sampled within three years of the tsunami. The sand layer forming the uppermost portion of this core was very similar to sediments covering most of the continental shelf at water depths of 15 to $22 \mathrm{~m}$ (e.g., Feldens et al., 2009, 2010, 2012). This layer conformably covers units 2, 3 and 4 (>25 cm in thickness), which revealed many features of event deposits, such as poorly sorted sediments ranging from mud to gravel, muddy clasts, pieces of wood, laterites and pieces of red brick. The latter suggests that the sediments had material of terrigenous origin included. The changing character of the deposits (mud/sand/mud) may reflect changing flow velocities and directions, while minor changes in the $\mathrm{Ti} / \mathrm{Ca}$ log-ratio may reflect changes in sediment sources. Based on this evidence and the assumptions presented above, units 2-4 are interpreted as having been deposited during the passage of the tsunami wave train.

The potential tsunami deposits in the two cores differed from one another in terms of the number of units with event deposits, their sedimentary characteristics and the relative input of terrestrial material. These characteristics may have been related to the various water depths (9.6 and $14.4 \mathrm{~m}$ ), the distance offshore $(3.1$ and $7.2 \mathrm{~km})$, and variations in the hydrodynamics of tsunami waves. Video records of the 2004 tsunami, which show the situation offshore Khao Lak revealed a high variability in flow patterns, including the formation of giant gyres (e.g., Di Geronimo et al., 2009).

Although there is a supporting age control for one core (in core 051207-32, it was not possible to evaluate those data due to the lack of suitable sediments above and below the event layer) and there was no evidence of recent heavy storms in the area, one may consider that the event deposits were formed by storms or cyclones. Storm deposits (tempestites) in shallow environments may reveal many various features depending on local conditions. There are no studies of storm deposits on the inner shelf in the Andaman Sea. However, in general, shallow water storm deposits may be sandy or muddy and often have basal erosional contact, normal gradation, plane lamination, wave ripples, thicknesses ranging from a few to more than $30 \mathrm{~cm}$ and hummocky cross stratification (e.g., Einsele et al., 1991; Weidong et al., 1997; Allison et al., 2005). Storm deposits may contain only one or many of these features. Moreover, as indicated by modern examples (e.g., Allison et al., 2005), changing flow conditions are also observed during a hurricane, and near-bottom velocities can reach more than $1 \mathrm{~m} \mathrm{~s}^{-1}$. Thus, many characteristics of storms and tsunamis over the continental shelf that affect sedimentation may be similar. The major features observed in the documented event layers, which are less likely, or unlikely, in storm deposits are: the frequent presence of terrestrial components, poor sorting and a massive character of some layers. Terrestrial components may be found in storm deposits if there is a big river nearby and can also occur due to coastal erosion. How- ever, storms primarily tend to erode the coastline (beach, dune), while tsunamis may also deliver terrestrial material further inland such as human artefacts and plants. The poor sorting and massive character of sediments may indicate a kind of sediment gravity mass flow (expected during backwash). Gravity mass flows are also known to be generated by storms, for instance in form of wave-induced fluid mud flows (e.g., Nittrouer et al., 2007). However, the fluid mud flow deposits are usually better sorted, do not include oversized clasts and contain less terrestrial material when compared with tsunami deposits.

Sediments in core 031207-23 were taken from a water depth of $57 \mathrm{~m}$. Distinct event layers were not recognised in this core, suggesting that the 2004 tsunami had no or very limited depositional effect in this region, which is supported by conclusion of Szczuciński (2010) based on ${ }^{210} \mathrm{~Pb}$ analyses of sediment cores from the mid continental shelf offshore Khao Lak.

\subsection{Processes of offshore sedimentation by the tsunami}

Assuming that the interpretation of the event layers as tsunami deposits in cores 050310-C6 (unit 2) and 05120732 (units 2-4) is correct, these deposits may serve as a source of information about tsunami sedimentation processes.

In core 050310-C6 (water depth $9.6 \mathrm{~m}, 3.1 \mathrm{~km}$ offshore), unit 2 (interpreted as being a tsunami deposit) began with a subunit that is approximately $2 \mathrm{~cm}$ thick (2b). It is composed of horizontally laminated medium to coarse sand. This subunit showed no indication of terrigenous origin (the $\mathrm{Ti} / \mathrm{Ca}$ ratio was similar to that in the sediments beneath it). There are several processes able of forming laminated sandy deposits, including flows in the upper and lower flow regimes, storms and turbidity currents (Reineck and Wunderlich, 1998). In the case presented in this study, it is likely that the sand was transported from water depths of 15-22 m, where medium and coarse sands are common (Feldens et al., 2012), toward the shoreline during the runup phase. To confirm this fact, a detailed analysis of microfossils is recommended in the future. The transport of sand could occur as a unidirectional flow in lower or upper plane bed conditions. Later on, an erosional surface was created, along with the deposition of unit $2 \mathrm{a}$ (approximately $16 \mathrm{~cm}$ thick). The subunit is likely to have been deposited as a result of decelerating flow conditions because it revealed a normal gradation. Considering the largest size of pebbles found in the lower part of the unit, the water velocity had to be at least in the order of several tens of $\mathrm{cm} \mathrm{s}^{-1}$. This subunit contains many terrigenous components; moreover, its chemical composition is similar to the onshore sediments analysed (Fig. 6). Therefore, this unit probably was created during the backwash flow.

Units 2-4 in core 051207-32 (water depth $14.4 \mathrm{~m}$, located $7.2 \mathrm{~km}$ offshore) could be interpreted as tsunami deposits. Because the retrieved sediment core does not reach below unit 4 , it is unclear how the sequence of tsunami deposits begins. The lowermost unit is composed of massive consolidated mud with scattered gravel, pieces of wood, mud clasts and red brick fragments. Its chemical composition also suggests a terrigenous origin, and thus, this unit was most likely formed during backwash. This finding is sup- 
Table 2. Comparison of selected signatures of offshore tsunami deposits.

\begin{tabular}{|c|c|c|c|c|c|c|}
\hline Source of data & $\begin{array}{l}\text { van den Bergh } \\
\text { et al. }(2003)\end{array}$ & $\begin{array}{c}\text { Abrantes et al. } \\
\text { (2008) }\end{array}$ & $\begin{array}{l}\text { Goodman-Tchernov } \\
\text { et al. }(2009)\end{array}$ & $\begin{array}{l}\text { Paris et al. } \\
\text { (2010) }\end{array}$ & $\begin{array}{l}\text { Smedile et al. } \\
\text { (2011) }\end{array}$ & Present study \\
\hline Region & Java, Indonesia & $\begin{array}{l}\text { Portuguese } \\
\text { shelf off } \\
\text { Lisbon }\end{array}$ & $\begin{array}{l}\text { coastal zone of Israel, } \\
\text { Eastern } \\
\text { Mediterranean }\end{array}$ & $\begin{array}{l}\text { Sumatra, } \\
\text { Indonesia }\end{array}$ & $\begin{array}{l}\text { Augusta Bay, } \\
\text { Eastern Sicily, } \\
\text { Italy }\end{array}$ & $\begin{array}{l}\text { Andaman Sea, } \\
\text { Thailand }\end{array}$ \\
\hline $\begin{array}{l}\text { Age of tsunami } \\
\text { (AD) }\end{array}$ & 1883 & 1755,1969 & $\begin{array}{l}1630-1550 \mathrm{BC}, \\
115 \mathrm{AD}, 551 \mathrm{AD}\end{array}$ & 2004 & $\begin{array}{l}1169,1693,1908, \\
\text { and } 8 \text { other events }\end{array}$ & 2004 \\
\hline Distance offshore $(\mathrm{km})$ & $3-14$ & $6-15$ & $\sim 4$ & $0-5$ & 2 & $3-7$ \\
\hline Water depth (m) & $2-27$ & $88-105$ & $10-20$ & $10-25$ & 72 & $9-15$ \\
\hline $\begin{array}{l}\text { Thickness of tsunami } \\
\text { deposits }(\mathrm{cm})\end{array}$ & $1-48$ & $2-143$ & up to 40 & $\begin{array}{l}\text { boulder size up } \\
\text { to } 15 \mathrm{~m}\end{array}$ & few to about 30 & $20->25$ \\
\hline $\begin{array}{l}\text { Type of } \\
\text { sedimentary } \\
\text { contacts }\end{array}$ & $\begin{array}{l}\text { lower-sharp, } \\
\text { often erosional; } \\
\text { upper sharp or } \\
\text { blurred due to } \\
\text { bioturbations }\end{array}$ & $\begin{array}{l}\text { no visible } \\
\text { contact, sharp } \\
\text { contact, } \\
\text { erosional } \\
\text { surface }\end{array}$ & $\begin{array}{l}\text { erosional lower } \\
\text { contact }\end{array}$ & sharp & not visible, sharp & $\begin{array}{l}\text { lower-sharp, } \\
\text { erosional; } \\
\text { upper-sharp }\end{array}$ \\
\hline Grain size & $\begin{array}{l}\text { sand, gravel } \\
\text { (mainly } \\
\text { carbonate) and } \\
\text { mud size tephra }\end{array}$ & $\begin{array}{l}\text { mud, sand and } \\
\text { gravels }\end{array}$ & $\begin{array}{l}\text { sandy mud, muddy } \\
\text { sand, pebbles }\end{array}$ & $\begin{array}{l}\text { sand, boulders } \\
\text { of various sizes } \\
\text { (up to } 15 \mathrm{~m} \text { ) }\end{array}$ & $\begin{array}{l}\text { sandy mud; often } \\
\text { with bimodal } \\
\text { grain size } \\
\text { distribution }\end{array}$ & $\begin{array}{l}\text { mud, sand, } \\
\text { gravels and } \\
\text { pebbles }\end{array}$ \\
\hline Sediment sorting & poorly sorted & $\begin{array}{l}\text { well sorted, } \\
\text { poorly sorted }\end{array}$ & poorly sorted & poorly sorted & $\begin{array}{l}\text { moderately to } \\
\text { poorly sorted }\end{array}$ & poorly sorted \\
\hline $\begin{array}{l}\text { Terrigenous } \\
\text { components }\end{array}$ & $\begin{array}{l}\text { volcanic rock } \\
\text { fragments }\end{array}$ & no & $\begin{array}{l}\text { organic material, } \\
\text { pumice }\end{array}$ & trees & no & $\begin{array}{l}\text { wood, mud } \\
\text { clasts, laterite }\end{array}$ \\
\hline $\begin{array}{l}\text { Anthropogenic } \\
\text { artifacts }\end{array}$ & no & no & pottery & yes & no & brick pieces \\
\hline Fossils & $\begin{array}{l}\text { abundant } \\
\text { broken shells; } \\
\text { presence of } \\
\text { autochthonous } \\
\text { (e.g. Turritellas) } \\
\text { and allochthonous } \\
\text { (e.g. oysters) } \\
\text { organisms }\end{array}$ & $\begin{array}{l}\text { shell } \\
\text { fragments }\end{array}$ & $\begin{array}{l}\text { molluscs; change in } \\
\text { foraminifera and } \\
\text { diatom assemblages }\end{array}$ & coral boulders & $\begin{array}{l}\text { significant } \\
\text { amount of } \\
\text { displaced } \\
\text { epiphytic benthic } \\
\text { foraminifera }\end{array}$ & shells \\
\hline $\begin{array}{l}\text { Geochemical } \\
\text { indicators }\end{array}$ & $\begin{array}{l}\text { variable } \mathrm{Ca} \\
\text { and } \mathrm{Mn}\end{array}$ & $\begin{array}{l}\text { variable } \mathrm{Fe} \\
\text { and } \mathrm{Ca} \\
\text { content }\end{array}$ & not studied & not studied & no & $\begin{array}{l}\text { variable } \mathrm{Ti} / \mathrm{Ca} \\
\text { ratio }\end{array}$ \\
\hline $\begin{array}{l}\text { Number of } \\
\text { layers }\end{array}$ & $1->6$ & 1 & $1-2$ & 1 & 1 & $2->3$ \\
\hline $\begin{array}{l}\text { Sedimentary } \\
\text { structures }\end{array}$ & $\begin{array}{l}\text { fining upward, } \\
\text { laminated, } \\
\text { coarsening } \\
\text { upward at the } \\
\text { base, shell } \\
\text { layers }\end{array}$ & $\begin{array}{l}\text { laminations, } \\
\text { turbidite }\end{array}$ & $\begin{array}{l}\text { imbrication, rip-up } \\
\text { clasts, fining upward } \\
\text { sequence }\end{array}$ & $\begin{array}{l}\text { lobe shaped } \\
\text { boulders } \\
\text { arrangement; } \\
\text { segregation of } \\
\text { boulders with } \\
\text { distance }\end{array}$ & not reported & $\begin{array}{l}\text { laminations, } \\
\text { massive } \\
\text { structures, } \\
\text { fining upward } \\
\text { sequence, } \\
\text { internal } \\
\text { erosional } \\
\text { surfaces }\end{array}$ \\
\hline $\begin{array}{l}\text { Presence of } \\
\text { tephra layer }\end{array}$ & $\begin{array}{l}\text { tephra and } \\
\text { pumices }\end{array}$ & no & pumices & no & $\begin{array}{l}\text { tephra is present } \\
\text { but not related to } \\
\text { the tsunami } \\
\text { deposits }\end{array}$ & no \\
\hline $\begin{array}{l}\text { Presence of }{ }^{210} \mathrm{~Pb} \\
\text { event like profile }\end{array}$ & $\begin{array}{l}{ }^{210} \mathrm{~Pb} \text { used for } \\
\text { age control }\end{array}$ & yes & not studied & not studied & no & yes \\
\hline
\end{tabular}

ported by the presence of over-sized clasts "floating" in the finer sediment mass and by a relatively high sediment consolidation. This subunit was approximately $5 \mathrm{~cm}$ thick and was covered by coarse sand and gravel with a massive appearance. The $\mathrm{Ti} / \mathrm{Ca}$ log-ratio in this thin layer was lower than that of the layer below, so these sediments may have no, or a lower, terrigenous contribution. The lack of clear lamination suggests that the deposition was rapid. The sand was covered by a complex, stiff mud with many over-sized compounds of sand and gravel (unit 2), which is very similar to the lowermost portion of unit 4 . This finding is interpreted as being an effect of the backwash flow, although the 
terrestrial contribution is not clear in the sediment geochemistry. However, during the backwash from the second wave, the inundated land was already mostly covered with water (e.g., Choowong et al., 2008), so there was much less erosion on land than during the first wave backwash phase. The upper part of this unit was partly laminated and reflected an upward fining in grain size. It is possible that the sedimentgravity flow evolved, due to a decrease in flow density, into simple settling from suspension, or that the unit represents two (or more) events (or pulses).

\subsection{Diagnostic features of offshore tsunami deposits}

Onshore tsunami deposits are characterised by a complex set of diagnostic features that have been presented in many studies (e.g., Dawson and Shi, 2000; Goff et al., 2001; Shiki et al., 2008; Bourgeois, 2009; Mamo et al., 2009; ChaguéGoff, 2010; Goto et al., 2010; Chagué-Goff et al., 2011). However, such criteria have not yet been summarised for offshore tsunami deposits, and the published data are limited. In the literature, offshore tsunami deposits are frequently related not only to the direct effect of deposition from tsunami-induced water flow (run-up or backwash), but also to tsunami-induced secondary processes such as turbidity currents (Dawson and Stewart, 2007; Shiki et al., 2008) and formation processes of so-called "homogenites" (Cita et al., 1996). The present discussion is limited to the recent shallow water deposits most likely formed due to direct deposition from tsunamis.

Table 2 summarises major features of tsunami deposits on the inner shelf or within $15 \mathrm{~km}$ of land that were generated by the eruption of Santorini in ca. 1630-1550 BC (Goodman-Tchernov et al., 2009), the eruption of Krakatau in 1883 (van den Bergh et al., 2003), earthquakes on the Portuguese margin in 1755 and 1969 (Abrantes et al., 2008), several tsunamis in the Mediterranean (Smedile et al., 2011) and the 2004 Indian Ocean tsunami (Paris et al., 2010 and present study). Several sedimentological studies (e.g., Massari and D’Alessandro, 2000; Takashimizu and Masuda, 2000; Fujiwara and Kamataki, 2007) on potential shallow marine tsunami deposits from the geological past are not included in the discussion because they are not related to a specific tsunami event but are interpreted as being tsunami-generated based on sedimentological properties. The comparison proves how variable offshore tsunami deposits can be. The deposits may form an event layer several $\mathrm{cm}$, several tens of $\mathrm{cm}$ or even over $1 \mathrm{~m}$ thick. The layers tend to have sharp lower contacts, which are often erosional. The upper contact may be blurred by bioturbations. They are composed of all grain size classes; often several classes are present in one layer resulting in poor sorting. Frequently, offshore tsunami deposits contain some typical terrigenous particles (wood, plants, etc.) and, if available, human-made pottery, brick, etc. This finding suggests the important role of tsunami backwash flows in the formation of these deposits. The fossil assemblage within the event layers may represent organisms from various environments. There was a high degree of variation in typical geochemical indicators of marine $(\mathrm{Ca})$ or terrestrial origin $(\mathrm{Fe}, \mathrm{Mn}$, Ti). The tsunami deposits may appear in the form of a single layer or several layers and may present the whole range of sedimentary structures: laminations, fining or coarsen- ing upward, a massive structure, erosional surfaces, imbrications, lag deposits, etc. Finally, the key to the interpretation of these structures is accurate dating, with analyses such as ${ }^{210} \mathrm{~Pb}$ activity profiles being particularly helpful. For instance, in the case of 1969 tsunami deposits on the Portuguese shelf, there was no visible change in sediment properties apart from a slight change in the ${ }^{210} \mathrm{~Pb}$ profile (Abrantes et al., 2008).

The presented comparison of offshore tsunami deposit characteristics reveals that their interpretation may be even more difficult than in the case of onshore tsunami deposits. It appears that the identification will always have to be based on several characteristics and a broad knowledge of local conditions. Distinguishing offshore tsunami and storm deposits will be a considerable challenge for future studies.

\section{Conclusions}

The present study provided new evidence of probable 2004 Indian Ocean tsunami deposits left on the inner shelf of the Andaman Sea (Thailand) and identified the diagnostic sedimentological and geochemical properties of these deposits. The deposits were restricted to the shallow marine environment (water depths of 9-15 m) within $8 \mathrm{~km}$ of the shoreline. Deposition occurred during the run-up phase, causing landward redeposition of marine sand, and during backwash flow events, which also deposited terrigenous sediments. The transport and deposition of sediments were driven by several processes, including unidirectional flow in various flow regimes and high-density sediment-gravity flow.

Typical features of these event deposits included the following: a thickness in the order of $20-25 \mathrm{~cm}$, a wide range of grain sizes and poor sorting, in contrast to underlying and overlying sediments, the presence of several layers, marine sand alternating with poorly sorted mud with terrigenous and anthropogenic components, representing different hydrodynamic conditions (run-up and backwash phase).

Geochemical and geophysical analyses, and particularly ${ }^{210} \mathrm{~Pb}$ activity measurements, were helpful supplementary tools in the identification of event layers. However, the analysis of available data on offshore tsunami deposits showed that there is no single set of signatures that could be universally applied to identify these deposits. Future studies will need to include more proxies (microfossils and advanced geochemistry in particular) to establish an identification key for offshore tsunami deposits.

Acknowledgments. We are grateful to Phuket Marine Biological Center (PMBC) for supporting us with ship time of RV Chakratong Tongyai and RV Boonlert Pasook as well as with other facilities during field campaigns. We further thank Dr. Warner Brückmann and Dr. Dieter Garbe-Schönberg for supporting the MSCL and XRF scanner measurements. Gratitude is also expressed to Dr. Nils Anderson and Dr. Helmut Erlenkeuser for their helpful comments and ${ }^{210} \mathrm{~Pb}$ determination. We thank Dr. Björn Heise and Daniel Unverricht for their tremendous help and inspiring ideas. Acknowledgements are due to Dr. P. M. De Martini and Dr. C. Chagué-Goff for their very constructive and detailed reviews. This research was funded by Deutsche Forschungsgemeinschaft (DFG) grant SCHW 572/11, National Research Council of Thailand (NRCT) and DAAD (Deutscher Akademischer Aus- 
tausch Dienst) fellowship provided to Ms. Daroonwan Sakuna for a Ph.D. study at Kiel University.

\section{References}

Abrantes, F., U. Alt-Epping, S. Lebreiro, A. Voelker, and R. Schneider, Sedimentological record of tsunamis on shallow-shelf areas: The case of the $1969 \mathrm{AD}$ and $1755 \mathrm{AD}$ tsunamis on the Portuguese Shelf off Lisbon, Mar. Geol., 249, 283-293, 2008.

Allison, M. A., A. Sheremet, M. A. Goñi, and G. W. Stone, Storm layer deposition on the Mississippi-Atchafalaya subaqueous delta generated by Hurricane Lili in 2002, Continental Shelf Res., 25, 2213-2232, 2005. Bahlburg, H., M. Spiske, and R. Weiss, Comment on "Sedimentary features of tsunami backwash deposits in a shallow marine Miocene setting, Mejillones Peninsula, northern Chile" by G. Cantalamessa and C. Di Celma [Sediment. Geol., 178, 259-273, 2005], Sediment. Geol., 228, 77-80, 2010.

Bahr, A., F. Lamy, H. Arz, H. Kuhlmann, and G. Wefe, Late glacial to Holocene climate and sedimentation history in the NW Black Sea, Mar. Geol., 214, 309-322, 2005.

Bell, R., H. Cowan, E. Dalziell, N. Evans, M. Ó Leary, B. Rush, and L. Yule, Survey of impacts on the Andaman Coast, Southern Thailand following the great Sumatra-Andaman earthquake and tsunami of December 26, 2004, Bull. New Zealand Soc. Earthq. Eng., 38, 123-148, 2005.

Best, A. I. and D. E. Gunn, Calibration of marine sediment core loggers for quantitative acoustic impedance studies, Mar. Geol., 160, 137-146, 1999.

Blott, S. J. and K. Pye, Gradistat: a grain-size distribution and statistics package for the analysis of unconsolidated sediments, Earth Surf. Process. Landforms, 26, 1237-1248, 2001.

Bouma, A. H., Notes on X-ray interpretation of marine sediments, Mar. Geol., 2, 278-309, 1964.

Bourgeois, J., Geologic effects and records of tsunamis, in The Sea, Volume 15: Tsunamis, edited by Robinson, A. R. and E. N. Bernard, 53-91, Harvard University press, Amsterdam, 2009.

Brand, S., Typhoon havens handbook, in http://www.nrlmry.navy.mil/ port_studies/Havens_Handbook/thh-nc/0start.htm, edited by Brand, S., 2009.

Calvert, S. E. and T. F. Pedersen, Elemental proxies for paleoclimatic and paleoceanographic variability in marine sediments: interpretation and application, in Developments in Marine Geology, edited by HillaireMarcel, C. and A. de Vernal, 567-644, 2007.

Cantalamessa, G. and C. D. Celma, Sedimentary features of tsunami backwash deposits in a shallow marine Miocene setting, Mejillones Peninsula, northern Chile, Sediment. Geol., 178, 259-273, 2005.

Carpenter, R., M. L. Peterson, and J. T. Bennett, ${ }^{210} \mathrm{~Pb}$-derived sediment accumulation and mixing rates for the Washington continental slop, Mar. Geol., 48, 135-164, 1982.

Chagué-Goff, C., Chemical signatures of paleootsunamis: A forgotten proxy?, Mar. Geol., 271, 67-71, 2010.

Chagué-Goff, C., J.-L. Schneider, J. R. Goff, D. Dominey-Howes, and L. Strotz, Expanding the proxy toolkit to help identify past eventsLessons from the 2004 Indian Ocean Tsunami and the 2009 South Pacific Tsunami, Earth-Sci. Rev., doi:10.1016/j.earscirev.2011.03.007, 2011.

Choowong, M., N. Murakoshi, K. Hisada, P. Charusiri, T. Charoentitirat, V. Chutakositkanon, K. Jankaew, P. Kanjanapayont, and S. Phantuwongraj, 2004 Indian Ocean tsunami inflow and outflow at Phuket, Thailand, Mar. Geol., 248, 179-192, 2008.

Cita, M. A., A. Camerlenghi, and B. Rimoldi, Deep-sea tsunami deposits in the eastern Mediterranean: new evidence and depositional models, Sediment. Geol., 104, 155-173, 1996.

Crockett, J. S., C. A. Nittrouer, A. S. Ogston, and M. A. Goni, Variable styles of sediment accumulation impacting strata formation on a clinoform: Gulf of Papua, Papua New Guinea, in The Fly River, Papua New Guinea: Environmental Studies in an Impacted Tropical River System, edited by Bolton, B., 177-207, Elsevier, Amsterdam, 2008.

Dawson, A. G. and S. Shi, Tsunami deposits, Pure Appl. Geophys., 157, 875-897, 2000.

Dawson, A. G. and I. Stewart, Tsunami deposits in the geological record, Sediment. Geol., 200, 166-183, 2007.

Dawson, S., Diatom biostratigraphy of tsunami deposits: Examples from the 1998 Papua New Guinea Tsunami, Sediment. Geol., 200, 328-335, 2007.

Di Geronimo, I., M. Choowong, and S. Phantuwongraj, Geomorphology and superficial bottom sediments of Khao Lak coastal area (SW Thai- land), Polish J. Environ. Stud., 18, 111-121, 2009.

Einsele, G., W. Ricken, and A. Seilchaer, in Cycles and Events in Stratigraphy, edited by Einsele, G., W. Ricken, and A. Seilchaer, 955 pp., Springer-Verlag, Berlin, Heidelberg, New York, 1991.

Feldens, P., K. Schwarzer, W. Szczuciński, K. Stattegger, D. Sakuna, and P. Somgpongchaiykul, Impact of 2004 tsunami on seafloor morphology and offshore sediments, Pakarang Cape, Thailand, Polish J. Environ. Stud., 18, 63-68, 2009.

Feldens, P., D. Sakuna, P. Somgpongchaiykul, and K. Schwarzer, Shallow water structures in a tsunami-affected area (Pakarang Cape, Thailand), in From Brazil to Thailand-New Results in Coastal Research, Coastline Reports, edited by Schwarzer, K., K. Schrottke, and K. Stattegger, 16, 15-24, 2010.

Feldens, P., K. Schwarzer, D. Sakuna, W. Szczuciński, and P. Sompongchaiyakul, Sediment distribution on the inner continental shelf off Khao Lak (Thailand) after the 2004 Indian Ocean tsunami, Earth Planets Space, 64, 875-887, 2012.

Fujiwara, O. and T. Kamataki, Identification of tsunami deposits considering the tsunami waveform: An example of subaqueous tsunami deposits in Holocene shallow bay on southern Bobo Penisular, Central Japan, Sediment. Geol., 200, 295-313, 2007.

Goff, J. C., C. Chagué-Goff, and S. Nichol, Paleotsunami deposits; a New Zealand Perspective, Sediment. Geol., 143, 1-6, 2001.

Goodman-Tchernov, B. N., H. W. Dey, E. G. Reinhard, F. McCoy, and Y. Mart, Tsunami waves generated by the Santorini eruption reached Eastern Mediterranean shores, Geology, 37, 943-946, 2009.

Goto, K., S. A. Chavanich, F. Imamura, P. Kunthasap, T. Matsui, K. Minoura, D. Sugawara, and H. Yanagisawa, Distribution, origin and transport process of boulders deposited by the 2004 Indian Ocean tsunami at Pakarang Cape, Thailand, Sediment. Geol., 202, 821-837, 2007.

Goto, K., T. Kawana, and F. Imamura, Historical and geological evidence of boulders deposited by tsunamis, southern Ryukyu Islands, Japan, Earth-Sci. Rev., 102, 77-99, 2010.

Goto, K., J. Takahashi, T. Oie, and F. Imamura, Remarkable bathymetric change in the nearshore zone by the 2004 Indian Ocean tsunami: Kirinda Harbor, Sri Lanka, Geomorphology, 127, 107-116, 2011.

Hawkes, A. D., M. Bird, S. Cowie, C. Grundy-Warr, B. P. Horton, A. Hwai, L. Law, C. Macgregor, J. Nott, J. E. Ong, J. Rigg, R. Robinson, M. Tan-Mullins, T. T. Sa, Z. Yasin, and L. W. Aik, Sediments deposited by the 2004 Indian Ocean Tsunami along the Malaysia-Thailand Penisula, Mar. Geol., 242, 169-190, 2007.

Heise, B., B. Bobertz, and J. Harff, Classification of the Perl River Estuary via Principal Component Analysis and Regionalisation, J. Coast. Res., 26, 769-779, 2010 .

Hofmann, D. I., K. Fabian, F. Schneider, B. Donner, and U. Bleil, A stratigraphic network across the Subtropical Front in the central South Atlantic: Multi-parameter correlation of magnetic susceptibility, density, $\mathrm{X}$-ray fluorescence and $\delta^{18} \mathrm{O}$ records, Earth Planet. Sci. Lett., 240, 694 709, 2005.

Jaeger, J. M., C. A. Nittrouer, N. D. Scott, and J. D. Milliman, Sediment accumulation along a glacially impacted mountainous coastline: Northeast Gulf of Alaska, Basin Res., 10, 155-173, 1998.

Jankaew, K., B. F. Atwater, Y. Sawai, M. Choowong, T. Charoentitirat, M. E. Martin, and A. Prendergast, Medieval forewarning of the 2004 Indian Ocean tsunami in Thailand, Nature, 455, 1228-1231, 2008.

Jansen, J. H. F., S. J. Van der Gaast, B. Koster, and A. J. Vaars, CORTEX, a shipboard XRF-scanner for element analyses in split sediment cores, Mar. Geol., 151, 143-153, 1998.

Kennedy, J., B. Barry, A. Markwitz, K. Srisuksawad, and A. Limsakul, Pixe analysis of sediments affected by the December 2004 Indian Ocean Tsunami, Int. J. PIXE, 18, 227-240, 2008.

Khokiattiwong, S., P. Limpsaichol, S. Petpiroon, P. Sojisuporn, and B. Kjerfve, Oceanographic variations in Phangnga Bay, Thailand under monsoonal effects, Phuket Mar. Biol. Cent. Res. Bull., 55, 43-76, 1991.

Kortekaas, S. and A. G. Dawson, Distinguishing tsunami and storm deposits: An example from Martinhal, SW Portugal, Sediment. Geol., 200, 208-221, 2007.

Kumar, V. S., V. R. Babu, M. T. Babu, G. Dhinakaran, and G. V. Rajamanickam, Assessment of storm surge disaster potential for the Andaman Islands, J. Coast. Res., 24, 171-177, 2008.

Lamy, F., D. Hebbeln, U. Röhl, and G. Wefer, Holocene rainfall variability in southern Chile: a marine record of latitudinal shifts of the Southern Westerlies, Earth Planet. Sci. Lett., 185, 369-382, 2001.

Le Roux, J. P. and G. Vargas, Hydraulic behaviour of tsunami backflows: insights from their modern and ancient deposits, Environ. Geol., 49, 6575,2005 
Luque, L., J. Lario, C. Zazo, J. L. Goy, C. J. Dabrio, and P. G. Silva, Tsunami deposits as paleoseismic indicators: Examples from the Spanish coast, Acta Geol. Hispanica, 36, 197-211, 2001.

Mamo, B., L. Strotz, and D. Dominey-Howes, Tsunami sediments and their foraminiferal assemblages, Earth-Sci. Rev., 96, 263-278, 2009.

Marques, W. S., A. N. Sial, E. A. Menor, V. P. Ferreira, G. S. S. Freire, E. A M. Lima, and V. A. V. Manso, Principal component analysis (PCA) and mineral associations of litoraneous facies of continental shelf carbonates from northeastern Brazil, Cont. Shelf Res., 28, 2709-2717, 2008.

Massari, F. and A. D'Alessandro, Tsunami-related scour-and-drape undulations in Middle Pliocene restricted-bay carbonate deposits (Salento, south Italy), Sediment. Geol., 135, 265-281, 2000.

McKee, B. A., C. A. Nittrouer, and D. J. DeMaster, The concepts of sediment deposition and accumulation applied to the continental shelf near the mouth of the Yangtze River, Geology, 11, 631-633, 1983.

Nittrouer, C. A., R. W. Sternberg, R. Carpenter, and J. T. Bennett, The use of $\mathrm{Pb}-210$ geochronology as a sedimentological tool: Application to the Washington continental shelf, Mar. Geol., 31, 297-316, 1979.

Nittrouer, C. A., J. A. Austin, M. E. Field, J. H. Kravitz, J. P. M. Syvitski, and P. Wiberg, in Continental Margin Sedimentation, edited by Nittrouer, C. A., J. A. Austin, M. E. Field, J. H. Kravitz, J. P. M. Syvitski, and P. Wiberg, 560 pp., International Association of Sedimentologists, Spec. Publ., 37, 2007.

Noda, A., H. Katayama, T. Sagayama, K. Suga, Y. Uchida, K. Satake, K. Abe, and Y. Okamura, Evaluation of tsunami impacts on shallow marine sediments: An example from the tsunami caused by the 2003 Tokachioki earthquake, northern Japan, Sediment. Geol., 200, 314-327, 2007.

Ohta, T. and H. Arai, Statistical empirical index of chemical weathering in igneous rocks: A new tool for evaluating the degree of weathering, Chem. Geol., 240, 280-297, 2007.

Paris, R., J. Fournier, E. Poizot, S. Etienne, J. Mortin, F. Lavigne, and P. Wassmer, Boulder and fine sediment transport and deposition by the 2004 tsunami in Lhok Nga (western Banda Aceh, Sumatra, Indonesia): A coupled offshore-onshore model, Mar. Geol., 268, 43-54, 2010.

Reid, M. K. and K. L. Spencer, Use of principal components analysis (PCA) on estuarine sediment datasets: The effect of data pre-treatment, Environ. Poll., 157, 2275-2281, 2009.

Reineck, H. E. and F. Wunderlich, Lamination and laminated rhythmites in water-laid sands, Senckenbergiana Maritima, 28, 227-235, 1998.

Robbins, J. A. and D. N. Edgington, Determination of recent sedimentation rates in Lake Michigan using Pb-210 and Cs-137, Geochim. Cosmochim. Acta, 39, 285-304, 1975.

Robbins, J. A., D. N. Edgington, and A. L. W. Kemp, Comparative ${ }^{210} \mathrm{~Pb}$, $137 \mathrm{Cs}$, and pollen geochronologies of sediments from Lakes Ontario and Erie, Quatern. Res., 10, 256-278, 1978.

Sawai, Y., K. Jankaew, M. E. Martin, A. Prendergast, M. Choowong, and T. Charoentitirat, Diatom assemblages in tsunami deposits associated with the 2004 Indian Ocean tsunami at Phra Thong Island, Thailand, Mar. Micropaleontol., 73, 70-79, 2009.

Scheffers, A. and D. Kelletat, Sedimentological and geomorphologic tsunami imprints worldwide-a review, Earth-Sci. Rev., 63, 83-92, 2003.

Shanmugam, G., Process-sedimentological challenges in distinguishing paleo-tsunami deposits, Nat. Haz., doi:10.1007/s11069-011-9766-z, 2011.

Shiki, T., Y. Tsuji, T. Yamazaki, and K. Minoura, in Tsunamiites-Features and Implications, edited by Shiki, T., Y. Tsuji, T. Yamazaki, and K.
Minoura, 425 pp., Elsevier, Amsterdam, 2008.

Smedile, A., P. M. De Martini, D. Pantosti, L. Bellucci, P. Del Carlo, L. Gasperini, C. Pirrotta, A. Polonia, and E. Boschi, Possible tsunami signatures from an integrated study in the Augusta Bay offshore (Eastern Sicily-Italy), Mar. Geol., 281, 1-13, 2011.

Sommerfield, C. K. and C. A. Nittrouer, Modern accumulation rates and sediment budget for the Eel shelf: A flood-dominated depositional environment, Mar. Geol., 154, 227-241, 1999.

Sugawara, D., K. Minoura, N. Nemoto, S. Tsukawaki, K. Goto, and F. Imamura, Foraminiferal evidence of submarine sediment transport and deposition by backwash during the 2004 Indian Ocean tsunami), Island Arc, 18, 513-525, 2009.

Suppasri, A., S. Koshimura, and F. Imamura, Developing tsunami fragility curves based on satellite remote sensing and the numerical modeling of the 2004 Indian Ocean tsunami in Thailand, Nat. Haz. Earth Syst. Sci., 11, 173-189, 2011.

Szczuciński, W., Impacts of 2004 Indian Ocean tsunami on mid continental shelf of Andaman Sea, in The 3rd International Tsunami Field Symposium, 57-58,Program and abstracts, Sendai, Japan, 10-11 April, 2010, 2010.

Szczuciński, W., N. Chaimanee, P. Niedzielski, G. Rachlewicz, D. Saisuttichai, T. Tepsuwan, S. Lorenc, and J. Siepak, Environmental and geological impacts of the 26 December 2004 tsunami in coastal zone of Thailand-Overview of short and long-term effects, Polish J. Environ. Stud., 15, 793-810, 2006.

Szczuciński, W., K. Stattegger, and J. Scholten, Modern sediments and sediment accumulation rates on the narrow shelf off central Vietnam, South China Sea, Geo-Mar. Lett., 29, 47-59, 2009.

Takashimizu, Y. and F. Masuda, Depositional facies and sedimentary successions of earthquake-induced tsunami deposits in Upper Pleistocene incised valley fills, central Japan, Sediment. Geol., 135, 231-239, 2000.

Uchida, J. I., O. Fujiwara, S. Hasegawa, and T. Kamataki, Sources and depositional processes of tsunami deposits: Analysis using foraminiferal tests and hydrodynamic verification, Island Arc, 19, 427-442, 2010.

Usiriprisan, C., S. Chiemchindaratana, S. Shoosuwan, and Y. Chatrapakpong, Offshore Exploration for Tin and Heavy Minerals in the Andaman Sea, 224 pp., Department of Mineral Resources, Bangkok and UNDP, New York, 1987.

van den Bergh, G. D., W. Boer, H. de Haas, Tj. C. E. van Weering, and R. van Wijhe, Shallow marine tsunami deposits in Teluk Banten (NW Java, Indonesia), generated by the 1883 Krakatau eruption, Mar. Geol., 197, 13-34, 2003.

Weber, M. E., F. Niessen, G. Kuhn, and M. Wiedicke, Calibration and application of marine sedimentary physical properties using a multisensor core logger, Mar. Geol., 136, 151-172, 1997.

Weidong, D., Y. Baoguo, and W. Xiaogen, Studies of storm deposits in China: A review, Cont. Shelf Res., 17, 1645-1658, 1997.

Weltji, G. J. and R. Tjallingii, Calibration of XRF core scanners for quantitative geochemical logging of sediment cores: Theory and application, Earth Planet. Sci. Lett., 274, 423-438, 2008

Zaborska, A., J. Caroll, C. Papucci, and J. Pempowiak, Intercomparison of alpha and gamma spectrometry techniques used in ${ }^{210} \mathrm{~Pb}$ geochronology, J. Environ. Radioact., 93, 38-50, 2007.

D. Sakuna (e-mail: daroonwan@gpi.uni-kiel.de), W. Szczuciński, P. Feldens, K. Schwarzer, and S. Khokiattiwong 